\title{
Effect of Wastewater Irrigation on Trace Metal Accumulation in Spinach (Spinacia oleracea L.) and Human Health Risk
}

\author{
Ilker Ugulu ${ }^{1 *}$, Zafar Iqbal Khan ${ }^{2}$, Sidrah Rehman ${ }^{2}$, Kafeel Ahmad $^{2}$, \\ Mudasra Munir ${ }^{2}$ and Humayun Bashir ${ }^{2}$ \\ ${ }^{1}$ Faculty of Education, Usak University, Usak, Turkey. \\ ${ }^{2}$ Department of Botany, University of Sargodha, Sargodha, Pakistan. \\ *Corresponding Author Email: ilkerugulu@gmail.com \\ Received 24 February 2020, Revised 11 May 2020, Accepted 21 May 2020
}

\begin{abstract}
The present research determines the effect of wastewater for irrigation on heavy metal accumulation in vegetables in the example of spinach (Spinacia oleracea L.) and to evaluate human health risk from consumption. Trace metal values of $\mathrm{Cd}, \mathrm{Cu}, \mathrm{Cr}, \mathrm{Fe}, \mathrm{Zn}, \mathrm{Ni}$ and $\mathrm{Mn}$, were determined in the water, soil and plant samples by Atomic Absorption Spectrophotometer. Trace metal concentrations in spinach samples ranged from 0.29 to $0.37,0.14$ to $1.25,0.07$ to $0.67,1.12$ to $2.48,0.33$ to $0.38,1.92$ to 2.90 and 0.51 to $0.63 \mathrm{mg} / \mathrm{kg}$ for $\mathrm{Cd}, \mathrm{Cr}, \mathrm{Cu}, \mathrm{Fe}, \mathrm{Ni}, \mathrm{Zn}$ and $\mathrm{Mn}$, respectively. These values of trace metals were lower than the permissible limits except for $\mathrm{Cd}$. All health risk index (HRI) values except for $\mathrm{Cd}$ were less than 1 . However, the HRI values related to spinach samples irrigated with canal water and sugar mill water were generally higher than the values of the samples irrigated with groundwater. The HRI value of $\mathrm{Cd}$ was higher than 1 and consumers of such vegetables in which HRI of metal was greater than 1 will be at risk.
\end{abstract}

Keywords: Biomonitoring, Spinach, Vegetable, Heavy Metal

\section{Introduction}

Wastewater irrigation is an important source of agricultural irrigation especially in countries that have difficulties in terms of freshwater resources [1-4]. One of the most prominent problems faced by cities and factories is the discharge and disposal of wastewater. If the industrial and sewage wastewaters are not disposed of within the scope of appropriate solutions, they pose significant problems for the environment [5-11]. So, irrigation of agricultural soil by wastewater for a long period may lead to the accretion of trace metals in soils and vegetables [12-13]. Also, these metals can pass to animals and humans through the food chain and cause ecosystem-wide contamination. Potential health risks and food safety problems make this one of the most alarming environmental aspect [14-18].

The term heavy metal is used for metals with a density higher than $5 \mathrm{~g} / \mathrm{cm}^{3}$ in terms of physical properties. Some metals are indispensable for living beings, while others are highly toxic. However, indispensable metals are also known to be toxic after a certain amount for living beings. Many studies on the subject have shown that the use of industrial and sewage wastewater in agricultural irrigation causes heavy metal pollution in soil and plants [19-22]. High level of trace metals is present in the upper layer of soil due to wastewater irrigation. This depth zone is located in the root area of many crops [23]. For this reason, 
this layer has an important place in the uptake of plants from the soil.

Vegetables are one of the most important elements of human and animal nutrition. Necessary components of daily diet like protein, calcium, vitamins and other nutrients are supplied by vegetables. Vegetables may also store trace metals in their edible and non-edible parts [4]. Trace elements are essential for normal metabolic functions in plants, but at higher concentrations, these metals are toxic and can seriously interfere with physiological and biochemical functions [13]. $\mathrm{Cd}, \mathrm{Cu}, \mathrm{Cr}, \mathrm{Fe}, \mathrm{Zn}, \mathrm{Ni}$ and $\mathrm{Mn}$ are the type of heavy metals that react as micronutrients at minor concentrations, they act as toxic compounds at higher concentrations. Health issues produced by contaminated soil and vegetables have been widely reported throughout the world [24-28]. For this reason, determination of heavy metal accumulation values, especially in plants consumed as food, has an important place in the researches on environmental pollution.

Spinach (Spinacia oleracea L., Amaranthaceae) is grown in Pakistan and all over the world. $S$. oleracea is used in traditional medicine to treat constipation, alleviate stomach acidity, treat anaemia and as diuretic and carminative. With all these features, spinach is an important plant in terms of nutrition, protection against diseases and alternative medicine practices. Pakistan is an important agricultural country and the most important economic activity of the country is agriculture. However, there is a shortage of clean water in the country and wastewaters such as industrial wastewater and sewage water are widely used in agricultural irrigation. Studies showed that wastewater irrigation is effective in heavy metal accumulation for spinach, as in other agricultural products [22]. Also, the literature studies on the subject showed that the studies on the irrigation of spinach with wastewater, heavy metal accumulation and its effect on health are not sufficient. In this direction, the present research was aimed to determine the effect of using wastewater for irrigation on heavy metal accumulation in vegetables in the example of spinach (Spinacia oleracea L.) and to evaluate human health risk from the consumption.
Materials and Methods Study area

This study was performed in Khushab District of Punjab, Pakistan (Fig. 1). The maximum temperature measured in the region in the summer is about $50{ }^{\circ} \mathrm{C}$, and the minimum temperature recorded in the winter is about $12{ }^{\circ} \mathrm{C}$. Due to this temperate feature, the city of Khushab offers a favourable environment for agricultural applications.

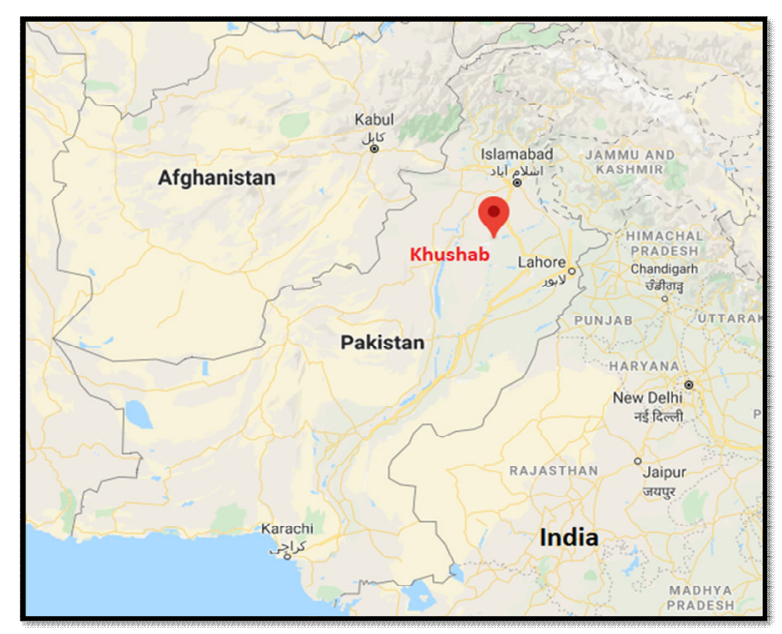

Figure 1. The map of study area

\section{Plant cultivation and sample preparation}

Spinach (Spinacia oleracea L.) samples were grown at the end of October 2016 in 60 small plastic pots. Approximately $2.5 \mathrm{~kg}$ of soil was filled to each plastic pot and a different treatment was applied in every 20 plastic pots. Ten seeds were sown in each plastic pot, and each pot was irrigated twice a week with a litre of groundwater (TI: GWI), canal water (TII: CWI) and sugar mill water (TIII: MWI). After the plant samples in the pots matured, only four plants were left in each pot and $210 \mathrm{~kg} \mathrm{ha}^{-1}$ urea fertilizer was applied to each pot.

The samples of water used in the irrigation of the pots were also taken as examples in the metal analysis. Soil samples were taken from the pots from a depth of $5 \mathrm{~cm}$ with the help of an auger. At the end of April 2017, spinach leaves were collected for analysis, dried outdoors and 
ground by pounding in a mortar. Ground powdered plant samples were dried in an oven for 3 days at $75{ }^{\circ} \mathrm{C}$. After it was completely dry, the samples were prepared for metal analysis using the Wet Digestion Method.

\section{Metal analysis}

$\mathrm{Cd}, \mathrm{Cu}, \mathrm{Cr}, \mathrm{Fe}, \mathrm{Zn}, \mathrm{Ni}$ and $\mathrm{Mn}$ amounts were determined in the water, soil and plant samples with the help of Atomic Absorption Spectrophotometer (Shimadzu model AA-6300). Table 1 shows the operating conditions used for each heavy metal in the analysis process.

Table 1. Operating conditions for the analysis of metals using atomic absorption spectrometry.

\begin{tabular}{|c|c|c|c|c|c|c|c|}
\hline \multicolumn{8}{|c|}{ Elements } \\
\hline Parameters & Cd & $\mathrm{Cr}$ & $\mathbf{C u}$ & $\mathbf{F e}$ & $\mathbf{N i}$ & Zn & $\mathbf{P b}$ \\
\hline Wavelength (nm) & 228.8 & 422.7 & 324.8 & 248.3 & 232.0 & 213.9 & 283.3 \\
\hline Slit width (nm) & 0.7 & 0.7 & 0.7 & 0.2 & 0.2 & 0.7 & 0.7 \\
\hline $\begin{array}{l}\text { Lamp current } \\
(\mathrm{mA})\end{array}$ & 8 & 10 & 6 & 12 & 12 & 8 & 10 \\
\hline $\begin{array}{l}\text { Air flow rate } \\
(\mathrm{L} / \mathrm{min})\end{array}$ & 15 & 15 & 15 & 15 & 15 & 15 & 15 \\
\hline $\begin{array}{l}\text { Acetylene flow } \\
\text { rate }(\mathrm{L} / \mathrm{min})\end{array}$ & 1.8 & 2.8 & 1.8 & 2.2 & 1.6 & 2 & 2.0 \\
\hline $\begin{array}{l}\text { Burner height } \\
\text { (mm) }\end{array}$ & 7 & 9 & 7 & 9 & 7 & 7 & 7 \\
\hline
\end{tabular}

\section{Statistical analysis}

The variance of the metal values for water, soil and vegetables were analysed by one-way ANOVA by SPSS 23. In evaluating the differences in metal concentrations in the samples, $0.001,0.01$ and 0.05 values were determined as the level of significance.

\section{Bioconcentration factor (BCF)}

Bioconcentration factor refers to metal accumulation in the plant as a result of the heavy metal transition from soil to plant. The following formula is used to calculate the bioconcentration factor:

$$
\mathrm{BCF}=\mathrm{C}_{\mathrm{veg}} / \mathrm{C}_{\text {soil }}
$$

While $\mathrm{C}_{\mathrm{veg}}$ refers to the metal accumulation value in plant tissues $(\mathrm{mg} / \mathrm{kg}$, fresh weight), $\mathrm{C}_{\text {soil }}$ refers to the metal concentration in the soil (mg/kg, dry weight) [12].

\section{Daily intake of metals (DIM)}

One of the certain methods considered to detect consumer-based health risks is the daily intake of metals. DIM was measured using the following formula:

Daily intake of metal $\mathrm{s}=\mathrm{C}_{\text {metal }} \times \mathrm{C}_{\text {food intake }} / \mathrm{B}_{\text {average weight }}$

While $\mathrm{C}_{\text {metal }}$ denotes metal concentration in plant samples, $\mathrm{C}_{\text {food intake }}$ indicates daily food intake and $B_{\text {average weight indicates average body }}$ weight. In this study, the daily food intake of a person was taken as $0.345 \mathrm{mg} / \mathrm{kg}$ and an average bodyweight of $60 \mathrm{~kg}$ as a standard.

\section{Health risk index (HRI)}

The HRI indicates a health threat to people who consume contaminated food. In this study, it was used to calculate the heavy metal exposure that can occur if spinach samples are consumed by humans. HRI is described as the ratio of DIM in food crops to the oral reference dose [9].

$$
\text { HRI = DIM / Oral reference dose }
$$

\section{Pollution load index (PLI)}

According to each metal value in the soil, PLI provides an estimation to the metal accumulation status. PLI was calculated for each treatment using the following formula [29]:

PLI $=$ Determined metal value of researched soil / Reference metal value of soil.

The reference trace metal values of soil for $\mathrm{Cd}(1.49 \mathrm{mg} / \mathrm{kg}), \mathrm{Cr}(9.07 \mathrm{mg} / \mathrm{kg}), \mathrm{Cu}(8.39$ $\mathrm{mg} / \mathrm{kg}), \mathrm{Ni}(9.06 \mathrm{mg} / \mathrm{kg}), \mathrm{Zn}(44.19 \mathrm{mg} / \mathrm{kg})$, and Mn $(46.75 \mathrm{mg} / \mathrm{kg})$ were taken according to Khan et al. [9] and $\mathrm{Fe}(56.90 \mathrm{mg} / \mathrm{kg})$ was taken according to Ahmad et al. [1].

\section{Results and Discussion \\ Trace metal concentration in water samples}

In the current study, the recorded Fe and $\mathrm{Zn}$ concentrations in the water samples used for 
irrigation were greater than other metal values (Fig. 2). However, it was observed that heavy metal accumulation values in canal and sugar mill water were higher than groundwater accumulation values. The ANOVA results indicated that there were no significant differences $(p>0.05)$ between the metal concentrations for $\mathrm{Cr}, \mathrm{Cd}, \mathrm{Cu}, \mathrm{Ni}$ and $\mathrm{Mn}$ while the significant differences for $\mathrm{Fe}$ and $\mathrm{Zn}$ in the water samples (Table 2).

The maximum permissible limits of the $\mathrm{Cd}, \mathrm{Cr}, \mathrm{Cu}, \mathrm{Fe}, \mathrm{Ni}, \mathrm{Zn}$ and $\mathrm{Mn}$ in water were reported by Standard Guidelines in Europe as $0.01,0.5,0.2,5,0.2,2$ and $0.2 \mathrm{mg} / \mathrm{L}$, respectively [30].
Trace metal values in water samples except Mn were above the maximum limits reported for water. In line with these results, it can be said that there is pollution in the waters used for irrigation in the study area. In the study conducted in Khushab, Khan et al. [9] noticed the metal values in groundwater, canal water and industrial water samples from the region as 0.01-0.02-0.03 $\mathrm{mg} / \mathrm{L}$ for $\mathrm{Cu}, 1.69-1.76-1.88 \mathrm{mg} / \mathrm{L}$ for $\mathrm{Cd}, 0.64-$ $0.72-0.83 \mathrm{mg} / \mathrm{L}$ for $\mathrm{Fe}, 0.54-0.57-0.65 \mathrm{mg} / \mathrm{L}$ for $\mathrm{Cr}, 0.08-0.10-0.14 \mathrm{mg} / \mathrm{L}$ for $\mathrm{Ni}, 0.07-0.08-0.12$ $\mathrm{mg} / \mathrm{L}$ for $\mathrm{Mn}$ and $0.57-0.61-0.66 \mathrm{mg} / \mathrm{L}$ for $\mathrm{Zn}$, respectively. The metal values obtained from this study were found above the maximum permissible limits by USEPA [31].

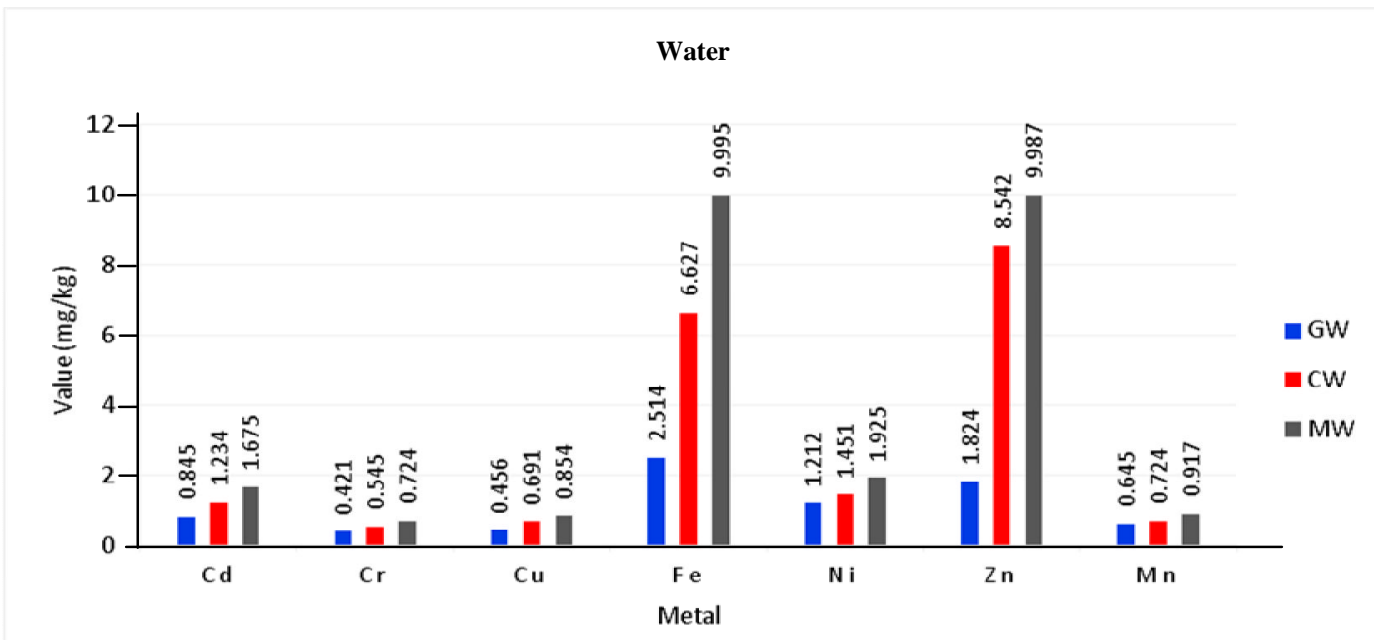

Figure 2. Trace metal concentrations in irrigation water

Table 2. Analysis of variance for heavy metals and metalloids in soil and spinach.

\begin{tabular}{|c|c|c|c|c|c|c|c|c|c|}
\hline \multirow{2}{*}{ Sample } & \multirow{2}{*}{$\begin{array}{l}\text { Source of Variation } \\
\text { (SOV) }\end{array}$} & \multirow{2}{*}{$\begin{array}{c}\begin{array}{c}\text { Degree of } \\
\text { freedom } \\
\text { (df) }\end{array} \\
\end{array}$} & \multicolumn{7}{|c|}{ Mean Squares } \\
\hline & & & $C d$ & $\mathrm{Cr}$ & $C u$ & $F e$ & $N i$ & $Z n$ & $M n$ \\
\hline \multirow{3}{*}{ Water } & Treatments & 4 & $.215^{\mathrm{ns}}$ & $.002^{\mathrm{ns}}$ & $.364^{\mathrm{ns}}$ & $6.189^{*}$ & $.750^{\mathrm{ns}}$ & $.006^{* * * *}$ & $.186^{\mathrm{ns}}$ \\
\hline & & & & & & & & & \\
\hline & Error & 10 & .052 & .001 & .074 & .813 & .307 & .001 & .039 \\
\hline \multirow{3}{*}{ Soil } & Treatments & 4 & $.010^{*}$ & $.030 * *$ & $.026^{\mathrm{ns}}$ & $.534^{\mathrm{ns}}$ & $.001^{\mathrm{ns}}$ & $33.458^{* * * *}$ & $.050^{* * *}$ \\
\hline & & & & & & & & & \\
\hline & Error & 10 & .002 & .003 & .023 & 32.603 & .003 & 2.259 & .006 \\
\hline \multirow{3}{*}{ Spinach } & Treatments & 4 & $.006^{\mathrm{ns}}$ & $1.510^{\mathrm{ns}}$ & $.396^{\mathrm{ns}}$ & $204.0^{* * *}$ & $.002^{\mathrm{ns}}$ & $1.151^{*}$ & $.013^{\mathrm{ns}}$ \\
\hline & & & & & & & & & \\
\hline & Error & 10 & .004 & .623 & .219 & 16.956 & .001 & .281 & .006 \\
\hline
\end{tabular}




\section{Trace metal concentration in soil samples}

In the present study, the determined mean metal values in soil samples were $0.35,0.155$, $0.348,6.52,0.38,6.64$ and $5.20 \mathrm{mg} / \mathrm{kg}$ for $\mathrm{Cd}, \mathrm{Cr}$, $\mathrm{Cu}, \mathrm{Fe}, \mathrm{Ni}, \mathrm{Zn}$ and $\mathrm{Mn}$, respectively. The mean $\mathrm{Fe}$, $\mathrm{Zn}$ and $\mathrm{Mn}$ concentrations were higher, and the mean $\mathrm{Cd}$ and $\mathrm{Cr}$ concentrations were lesser among the three treatments (Fig. 3). These values also clearly showed that heavy metal accumulation values in soil samples irrigated with sugar mill water were higher than the metal accumulation values of soil samples irrigated with other waters. According to the statistical analysis, while different irrigation regimes produced a statistically significant difference in the accumulation of $\mathrm{Cd}$, $\mathrm{Cr}, \mathrm{Zn}$ and $\mathrm{Mn}$ in the soils where spinach was grown, it did not make a significant difference in terms of $\mathrm{Cu}, \mathrm{Fe}$ and $\mathrm{Ni}$ accumulation ( $\mathrm{p}>0.05)$ (Table 2).

USEPA [31] reported the maximum permissible limits in the soil for the accumulation of $\mathrm{Cd}, \mathrm{Cr}, \mathrm{Cu}, \mathrm{Fe}, \mathrm{Ni}, \mathrm{Zn}$ and $\mathrm{Mn}$ as 3, 100, 50, 21000, 50, 200 and $2000 \mathrm{mg} / \mathrm{kg}$, respectively. All metal values in the present research identified below permissible limits for all treatments. Findings of Alrawiq et al. [32] showed a higher amount of metals than the presented values in this study except for Cd. Many studies performed in Pakistan reported on the high concentration of trace metals in vegetables irrigated with industrial water or sewage sludge. Ahmad et al. [33] examined the heavy metal accumulation in the soil samples irrigated with wastewater and tap water in their study in Khushab, Pakistan, and found that the cobalt accumulation in the soil irrigated with sewage water $(20.2 \mathrm{mg} / \mathrm{kg})$ was more than irrigated with tap water $(13.5 \mathrm{mg} / \mathrm{kg})$. As mentioned in this study, it was concluded that heavy metal accumulation was higher as a result of irrigation with the sewage water. The reason for these results may be low adsorption property of this metal in soil [9]. However, many factors such as the geological characteristics of the soil of the region, industrial establishments in the environment, climate and precipitation can be shown among the factors affecting the heavy metal level in the soil.

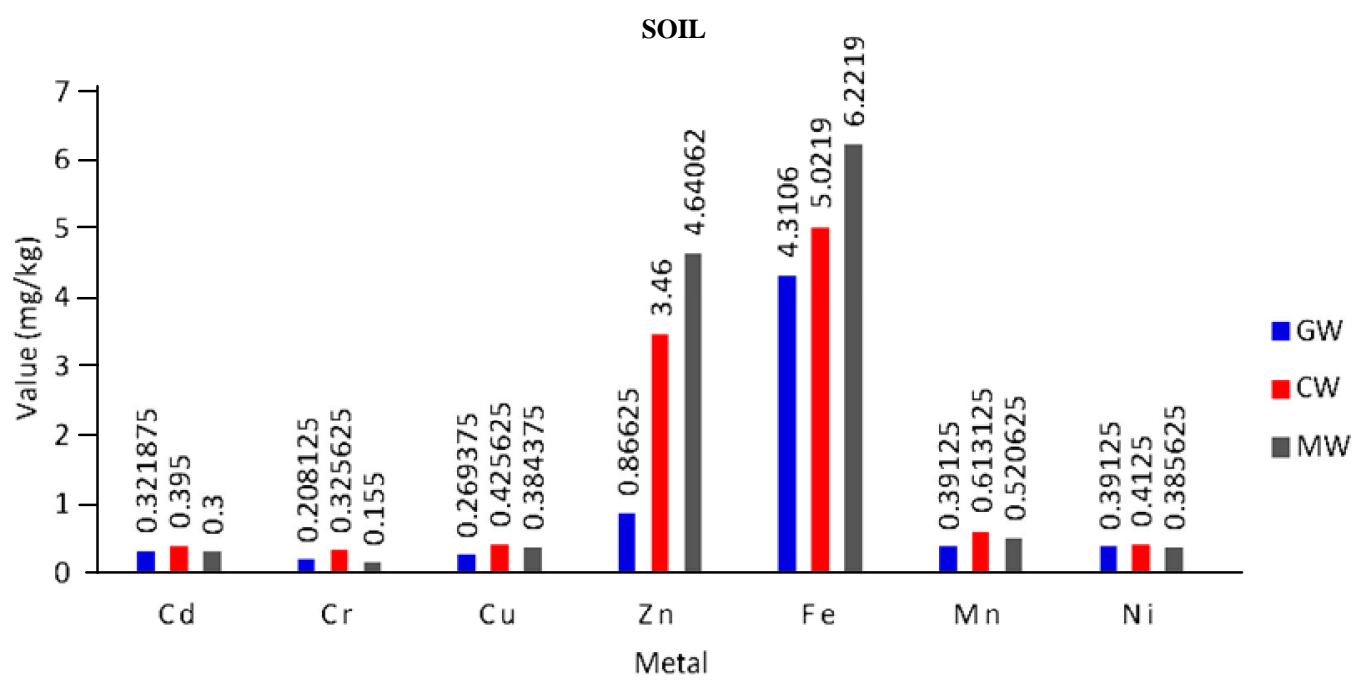

Figure 3. Fluctuation in metals in soil of spinach 


\section{Trace metal concentration in vegetable samples}

Trace metal concentrations in spinach samples ranged from 0.29 to $0.37,0.14$ to 1.25 , 0.07 to $0.67,1.12$ to $2.48,0.33$ to $0.38,1.92$ to 2.90 and 0.51 to $0.63 \mathrm{mg} / \mathrm{kg}$ for $\mathrm{Cd}, \mathrm{Cr}, \mathrm{Cu}, \mathrm{Fe}$, $\mathrm{Ni}, \mathrm{Zn}$ and $\mathrm{Mn}$, respectively. Among the three treatments, the mean $\mathrm{Fe}$ and $\mathrm{Zn}$ concentrations were higher in all treatments and the mean $\mathrm{Cr}$ and $\mathrm{Cu}$ concentrations were lesser in treatment I and II (Fig. 4). These values showed that heavy metal accumulation values in spinach samples irrigated with sugar mill water were higher than the metal accumulation values of spinach samples irrigated with other waters except $\mathrm{Cd}, \mathrm{Mn}$ and $\mathrm{Ni}$. According to the statistical analysis, while different irrigation regimes produced a statistically significant difference in the accumulation of $\mathrm{Cd}$, $\mathrm{Cr}, \mathrm{Cu}, \mathrm{Ni}$ and $\mathrm{Mn}$ in the spinach samples, it did not make a significant difference in terms of $\mathrm{Fe}$ and $\mathrm{Zn}$ accumulation ( $\mathrm{p}>0.05$ ) (Table 2).

USEPA [31] reported the maximum permissible limits in the plants for the accumulation of $\mathrm{Cd}, \mathrm{Cr}, \mathrm{Cu}, \mathrm{Fe}, \mathrm{Ni}, \mathrm{Zn}$ and $\mathrm{Mn}$ as $0.1,5, \quad 73,425,67,100$ and $500 \mathrm{mg} / \mathrm{kg}$, respectively. The range values of trace metals in spinach samples were lower than these permissible limits except for $\mathrm{Cd}$. Also, the $\mathrm{Cd}$ concentration was considerably higher than the values $(0.002-$ $0.08 \mathrm{mg} / \mathrm{kg}$ ) in Egypt reported by Dogheim et al. [34]. However, the present $\mathrm{Cd}$ values were lesser than the vegetables studied by Gupta et al. [35] in India $(10.37-17.79 \mathrm{mg} / \mathrm{kg}$ ) and within the range $(0.03-0.73 \mathrm{mg} / \mathrm{kg})$ noted by Liu et al. [36] in China. Demirezen and Aksoy [37] examined various vegetables and determined that $\mathrm{Zn}$ contents were in the range of $3.56-4.59 \mathrm{mg} / \mathrm{kg}$ which was higher than the present study as in the range from 1.92 to $2.90 \mathrm{mg} / \mathrm{kg}$. Ahmad et al. [33] observed a higher range of cobalt in the root samples $(1.07-1.26 \mathrm{mg} / \mathrm{kg})$ of the plants irrigated with the sewage water. As mentioned in this study, it was concluded that heavy metal accumulation was higher as a result of irrigation with the sewage water. The main factors that affect the heavy metal intake of plants from the soil are factors such as $\mathrm{pH}$, temperature, cation exchange capacity of the soil, the rate of other metals in the soil, chemical selectivity, oil value and species of the plant [29]. In line with the findings obtained from this study, it can be said that the use of wastewater for irrigation increases the heavy metal accumulation in the soil and maybe the reason for the high heavy metal level in other factors mentioned above.

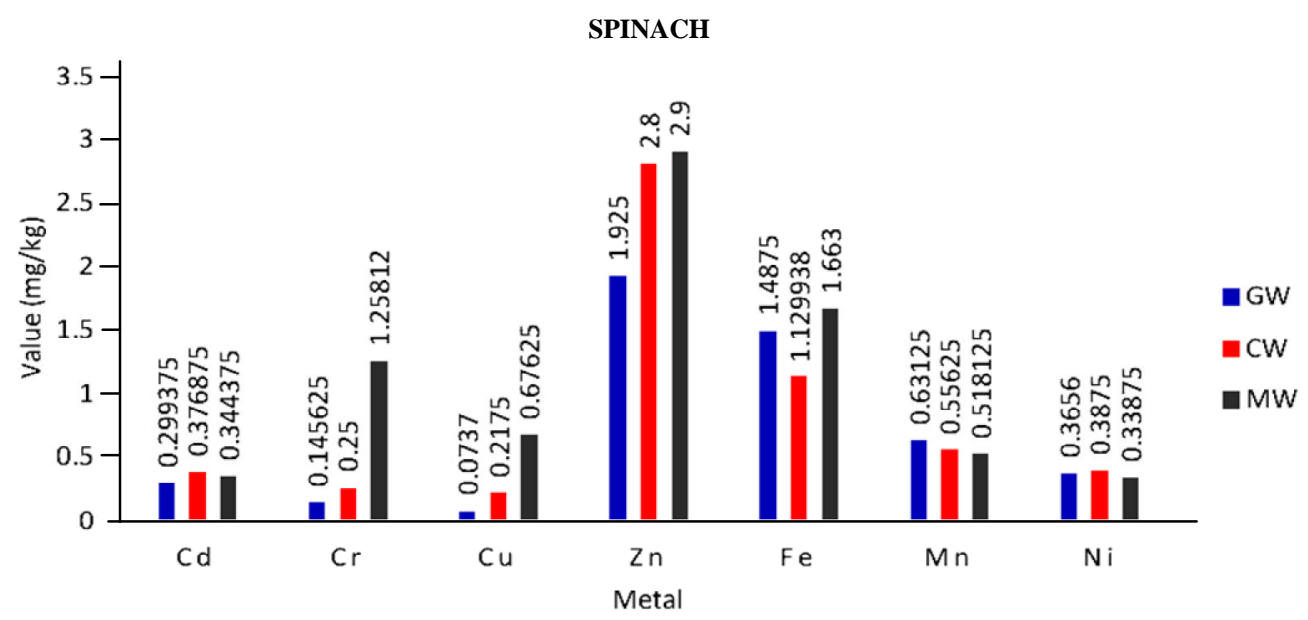

Figure 4. Fluctuation of metals in spinach 


\section{Bioconcentration factor (BCF)}

Analysis of various metals in three irrigations, $\mathrm{Zn}$ showed the maximum and $\mathrm{Cu}$ showed the minimum value in groundwater treatment. In treatment-I (GWI), transfer factor for $\mathrm{Cr}, \mathrm{Fe}$ and $\mathrm{Cu}$ was lower than $\mathrm{Cd}, \mathrm{Mn}, \mathrm{Ni}$ and $\mathrm{Zn}$. In treatment-II (CWI), transfer factor for $\mathrm{Zn}, \mathrm{Fe}$, $\mathrm{Cu}$ and $\mathrm{Cr}$ was lower as compared to $\mathrm{Cd}, \mathrm{Mn}$ and Ni. Finally, in treatment-III (MWI), Fe, Zn and Ni values were lower than the values of $\mathrm{Cr}, \mathrm{Cu}, \mathrm{Cd}$ and $\mathrm{Mn}$ (Table 3). Bioconcentration factor values for $\mathrm{Cd}, \mathrm{Cr}, \mathrm{Cu}$ and $\mathrm{Zn}$ in spinach samples irrigated with sugar mill water and $\mathrm{Mn}$ and $\mathrm{Zn}$ values in samples irrigated with groundwater were found higher than 1. The BCF is the best way to know the availability of important metals transferred from soil to grow vegetable. The BCF values of $\mathrm{Cd}, \mathrm{Cr}, \mathrm{Cu}$ and $\mathrm{Zn}$ in sugar mill irrigated samples, and the $\mathrm{BCF}$ values of $\mathrm{Mn}$ and $\mathrm{Zn}$ in groundwater irrigated samples were higher than 1, which shows that these metals were easily available to vegetables and diffused more in them [1]. The mean values for BCF reported by Ahmad et al. [33] were 0.036 and 0.038 for Co in Brassica rapa grown at tap water and sewage water irrigated sites, respectively. Although it was close to each other, it was observed that BCF value in wastewater irrigation area is higher like as in the present study.

Table 3. Bioconcentration factor for spinach.

\begin{tabular}{cccccccc}
\hline \multirow{2}{*}{ Irrigations } & $\boldsymbol{C} \boldsymbol{d}$ & $\boldsymbol{C r}$ & $\boldsymbol{C u}$ & $\boldsymbol{F e}$ & $\boldsymbol{N i}$ & $\boldsymbol{Z n}$ & $\boldsymbol{M n}$ \\
\cline { 2 - 8 } I & 0.9300 & 0.699 & 0.273 & 0.42 & 0.934 & 2.22 & 1.613 \\
II & 0.954 & 0.767 & 0.511 & 0.187 & 0.939 & 0.809 & 0.907 \\
III & 1.147 & 8.116 & 1.759 & 0.254 & 0.878 & 1.836 & 0.995
\end{tabular}

\section{Pollution load index (PLI)}

PLI values for spinach grown with three different irrigations was in the following sequence. Order of PLI in treatment-I (GWI), treatment-II (CWI) and treatment-III (MWI) were $\mathrm{Cd}>\mathrm{Fe}>$ $\mathrm{Ni}>\mathrm{Cu}>\mathrm{Cr}>\mathrm{Zn}>\mathrm{Mn}, \quad \mathrm{Cd}>\mathrm{Fe}>\mathrm{Zn}>\mathrm{Cu}>\mathrm{Ni}>\mathrm{Cr}>\mathrm{Mn}$ and $\mathrm{Cd}>\mathrm{Fe}>\mathrm{Zn}>\mathrm{Cu}>\mathrm{Ni}>\mathrm{Cr}>\mathrm{Mn}$, respectively. The highest PLI was observed for $\mathrm{Cd}$ and the lowest PLI for $\mathrm{Cr}$ and $\mathrm{Mn}$ in all three irrigations (Table 4).
It was observed that the PLI values of the sugar mill water and canal water irrigated samples were higher than the groundwater irrigated samples. However, the measured values were lower than the values found by Khan et al. [16]. Higher PLI value (1.493) was noticed by Ahmad et al. [33] when the sewage source was used to irrigate the soil instead of tap water. In the study conducted in the region, Ahmad et al. [1] found the highest PLI value for Cd. In this direction, the results of the present study were parallel to the values reported by Ahmad et al. [1]. A PLI value greater than 1 indicates that the food is contaminated with metal, and less than 1 indicates that it is not contaminated [15]. The fact that the PLI values obtained as a result of the study were less than 1 indicates that the spinach samples are consumable.

\section{Daily intake of metals (DIM)}

DIM values for $\mathrm{Fe}$ and $\mathrm{Zn}$ were higher and $\mathrm{Cr}$ was the lowest value in sugar mill water and canal water treatments. The order of DIM values in in treatment-I (GWI), treatment-II (CWI) and treatment-III (MWI) were $\mathrm{Fe}>\mathrm{Zn}>\mathrm{Mn}>\mathrm{Ni}>\mathrm{Cd}>$ $\mathrm{Cr}>\mathrm{Cu}, \mathrm{Zn}>\mathrm{Fe}>\mathrm{Mn}>\mathrm{Ni}>\mathrm{Cd}>\mathrm{Cu}>\mathrm{Cr}$ and $\mathrm{Zn}>\mathrm{Fe}>$ $\mathrm{Cu}>\mathrm{Mn}>\mathrm{Cd}>\mathrm{Ni}>\mathrm{Cr}$, respectively (Table 5).

According to WHO/FAO, DIM values for $\mathrm{Cd}, \mathrm{Cr}, \mathrm{Cu}, \mathrm{Ni}$ and $\mathrm{Zn}$ were $0.06,0.05-0.2,3,1.4$, $60 \mathrm{mg} /$ day, respectively. The DIM values for all metals presented in this study are below the standard values. Mahmood and Malik [38] pointed out that, daily intake of metal was higher for $\mathrm{Zn}$ and less for $\mathrm{Cr}$ and $\mathrm{Cd}$ in foodstuff grown at wastewater. In the present study, the consequences of the DIM value of vegetables irrigated with sugar mill wastewater showed resemblance to that given by Mahmood and Malik [38].

\section{Health risk index (HRI)}

In the present study, the order of HRI values of the metals in treatment-I (GWI), treatment-II (CWI) and treatment-III (MWI) were $\mathrm{Cd}>\mathrm{Ni}>\mathrm{Mn}>\mathrm{Zn}>\mathrm{Fe}>\mathrm{Cu}>\mathrm{Cr}, \mathrm{Cd}>\mathrm{Ni}>\mathrm{Mn}>\mathrm{Zn}>\mathrm{Cu}>$ $\mathrm{Fe}>\mathrm{Cr}$ and $\mathrm{Cd}>\mathrm{Ni}>\mathrm{Cu}>\mathrm{Mn}>\mathrm{Zn}>\mathrm{Fe}>\mathrm{Cr}$, respectively (Table 6). The metal with the lowest health risk index for spinach samples in all 
irrigation environments was chromium. The fact that the calculated HRI value was greater than 1 indicates that the consumption of this food carries health risks and that less than 1 indicates that consumption is not a problem in terms of health [7]. In the present study, $\mathrm{Cd}$ value was higher than 1 and consumers of such vegetables in which HRI of metal was greater than 1 will be at risk [15]. On the other hand, although the HRI values were less than 1 , it was seen that the values related to spinach samples irrigated with canal water and sugar mill water were generally higher than the values of the samples irrigated with groundwater. A similar finding was reached by Ahmad et al. [33] and it was reported that HRI values were higher in products that were irrigated with wastewater. The HRI indicates a health threat to people who consume contaminated food [3940].

Table 5. Daily intake of metal for spinach.

\begin{tabular}{cccccccc}
\hline \multirow{2}{*}{ Irrigations } & \multicolumn{7}{c}{ Heavy Metals } \\
\cline { 2 - 8 } & $\boldsymbol{C} \boldsymbol{d}$ & $\boldsymbol{C r}$ & $\boldsymbol{C u}$ & $\boldsymbol{F e}$ & $\boldsymbol{N i}$ & $\boldsymbol{Z n}$ & $\boldsymbol{M n}$ \\
\hline I & 0.0017 & 0.00083 & 0.00042 & 0.01430 & 0.00210 & 0.01106 & 0.00362 \\
II & 0.00216 & 0.00143 & 0.00125 & 0.00649 & 0.00222 & 0.0161 & 0.00319 \\
III & 0.00198 & 0.00123 & 0.00388 & 0.00956 & 0.00194 & 0.01667 & 0.00297 \\
\hline
\end{tabular}

Table 6. Health risk index values.

\begin{tabular}{|c|c|c|c|c|c|c|c|}
\hline \multirow{2}{*}{ Irrigations } & \multicolumn{7}{|c|}{ Heavy Metals } \\
\hline & Cd & $\mathrm{Cr}$ & $\mathbf{C u}$ & $\mathbf{F e}$ & $\mathbf{N i}$ & $\mathbf{Z n}$ & Mn \\
\hline $\mathbf{I}$ & 1.721 & 0.002 & 0.0106 & 0.0204 & 0.1051 & 0.0368 & 0.0885 \\
\hline II & 2.167 & 0.0009 & 0.0312 & 0.0092 & 0.111 & 0.0536 & 0.0780 \\
\hline III & 1.980 & 0.0048 & 0.097 & 0.0136 & 0.0973 & 0.0555 & 0.072 \\
\hline
\end{tabular}

Table 7. Metal correlation between soil-vegetable.

\begin{tabular}{lc}
\hline \multicolumn{3}{c}{ Correlation } \\
\hline Metals & Soil-Vegetable \\
\hline $\mathrm{Cd}$ & .669 \\
$\mathrm{Cr}$ & -.680 \\
$\mathrm{Cu}$ & .476 \\
$\mathrm{Fe}$ & -.405 \\
$\mathrm{Ni}$ & .928 \\
$\mathrm{Zn}$ & .883 \\
$\mathrm{Mn}$ & -.721 \\
\hline
\end{tabular}

\section{Correlation}

The results presented positive nonsignificant correlation of $\mathrm{Cd}, \mathrm{Cu}, \mathrm{Zn}$ and $\mathrm{Ni}$ and negative non-significant correlation of $\mathrm{Cr}, \mathrm{Fe}$ and Mn (Table 7). Bibi et al. [17] reported that the correlation between soil and vegetable was positive and non-significant for $\mathrm{Cd}$ and $\mathrm{Ni}$. Results of correlation in the current study were similar to that study.

\section{Conclusion}

In the present study, $\mathrm{Cd}, \mathrm{Cr}, \mathrm{Cu}, \mathrm{Fe}, \mathrm{Ni}$, $\mathrm{Zn}$ and $\mathrm{Mn}$ values in Spinacia oleracea samples 
irrigated with groundwater, canal water and sugar mill water were examined. The values of the trace metals in spinach samples except $\mathrm{Cd}$ were below the maximum permissible limits. Also, these values showed that heavy metal accumulation values in spinach samples irrigated with sugar mill water were higher than the metal accumulation values of spinach samples irrigated with other waters except $\mathrm{Cd}, \mathrm{Mn}$ and $\mathrm{Ni}$. According to the findings of the study, health risk index value of $\mathrm{Cd}$ was higher than 1 and consumers of such vegetables in which HRI of metal was greater than 1 will be at risk. Even so, it can be said that legal measures should be taken and implemented sensitively by local governments and appropriate authorities.

\section{Acknowledgement}

Laboratory facilities are provided by High Tech Lab University of Sargodha. The authors also thank all the supporters for suggestions and comments for the improvement of this manuscript.

\section{References}

1. K. Ahmad, K. Nawaz, Z. I. Khan, M. Nadeem, K. Wajid, A. Ashfaq, B. Munir, H. Memoona, M. Sana, F. Shaheen, R. Kokab, S. Rehman, M. F. Ullah, N. Mehmood, H. Muqaddas, Z. Aslam, M. Shezadi, I. R. Noorka, H. Bashir, H. A. Shad, F. Batool, S. Iqbal, M. Munir, M. Sohail, M. Sher, S. Ullah, I. Ugulu, Y. Dogan, Fresen. Environ. Bull., $\quad 27 \quad$ (2018) 846. https://www.researchgate.net/publication/32 3144653

2. M. Nadeem, T. M. Qureshi, I. Ugulu, M. N. Riaz, Q. U. An, Z. I. Khan, K. Ahmad, A. Ashfaq, H. Bashir and Y. Dogan, Pak. J. Bot., 51 (2019) 171. http://doi.org/10.30848/PJB2019-1(14)

3. Z. I. Khan, I. Ugulu, S. Sahira, K. Ahmad, A. Ashfaq, N. Mehmood and Y. Dogan, Int. J. Environ. Res., 12 (2018) 503. https://doi.org/10.1007/s41742-018-0110-2

4. I. Ugulu, Appl. Spectrosc. Rev., 50(2) (2015) 113. https://doi.org/10.1080/05704928.2014.9359 $\underline{81}$
5. I. Ugulu, M. C. Unver and Y. Dogan, Oxid. Commun., 39 (2016) 765. http://scibulcom.net/ocr.php?gd=2016\&bk= $\underline{1}$

6. M. C. Unver, I. Ugulu, N. Durkan, S. Baslar and Y. Dogan, Ekoloji, 24 (2015) 13. https://doi.org/10.5053/ekoloji.2015.01

7. Y. Dogan, I. Ugulu and N. Durkan, Pak. J. Bot., 45 (2013) 177.

https://www.pakbs.org/pjbot/PDFs/45(SI)/2 4.pdf

8. I. Ugulu and S. Baslar, J. Altern. Complem. Med., 16 (2010) 313. http://doi.org/10.1089=acm.2009.0040

9. Z. I. Khan, I. Ugulu, S. Umar, K. Ahmad, N. Mehmood, A. Ashfaq, H. Bashir and M. Sohail, Bull. Environ. Contam. Toxicol., 101 (2018) 235.

https://doi.org/10.1007/s00128-018-2353-1

10. Y. Dogan, I. Ugulu and S. Baslar, Ekoloji, 19 (2010) 88.

http://doi.org/10.5053/ekoloji.2010.7512

11. N. Durkan, I. Ugulu, M. C. Unver, Y. Dogan and S. Baslar, Trace Elem. Electroly., 28 (2011) 242.

http://doi.org/10.5414/TEX01198

12. I. Ugulu, Y. Dogan, S. Baslar and O. Varol, Int. J. Environ. Sci. Technol., 9 (2012) 527. https://doi.org/10.1007/s13762-012-0056-4

13. Y. Dogan, S. Baslar and I. Ugulu, Appl. Ecol. Environ. Res., 12 (2014) 627. http://doi.org/10.15666/aeer/1203 627636

14. Y. Dogan, M.C. Unver, I. Ugulu, M. Calis and N. Durkan, Biotech. Biotechnol. Equip. 28 (2014) 643. http://doi.org/10.1080/13102818.2014.9470 $\underline{76}$

15. I. Ugulu, Int. J. Educ. Sci., 26 (2019) 49. https://doi.org/10.31901/24566322.2019/26. $1-3.1086$

16. Z. I. Khan, K. Ahmad, H. Safdar, I. Ugulu, K. Wajid, H. Bashir and Y. Dogan, Res. J. Pharm. Biol. Chem. Sci., 9 (2018) 759. https://www.rjpbcs.com/pdf/2018_9(5)/[94]. pdf

17. Z. I. Khan, I. Ugulu, S. Umar, K. Ahmad, N. Mehmood, A. Ashfaq, H. Bashir and M. Sohail, Bull. Environ. Contam. Toxicol., 101 (2018) 235. https://doi.org/10.1007/s00128-018-2353-1 
18. I. Ugulu, Biotech. Biotechnol. Equip., 29 (2015) 20.

http://doi.org/10.1080/13102818.2015.1047 $\underline{168}$

19. N. Yorek, I. Ugulu and H. Aydin, Comput. Intel. Neurosci., Article ID 2476256, (2016) 1.

http://dx.doi.org/10.1155/2016/2476256

20. I. Ugulu, Biotech. Biotechnol. Equip., 23 (2009) 14.

21. Z. I. Khan, I. Ugulu, K. Ahmad, S. Yasmeen, I. R. Noorka, N. Mehmood and M. Sher, Bull. Environ. Contam. Toxicol., 101 (2018) 787. https://doi.org/10.1007/s00128-018-2448-8

22. Z. I. Khan, K. Ahmad, S. Rehman, A. Ashfaq, N. Mehmood, I. Ugulu and Y. Dogan, Pak. J. Anal. Environ. Chem., 20 (2019) 60.

http://doi.org/10.21743/pjaec/2019.06.08

23. Z. I. Khan, H. Safdar, K. Ahmad, K. Wajid, H. Bashir, I. Ugulu and Y. Dogan, Pak. J. Bot., 52 (2020) 111.

http://dx.doi.org/10.30848/PJB2020-1(12)

24. I. Ugulu, Z. I. Khan, S. Rehman, K. Ahmad, M. Munir, H. Bashir and K. Nawaz, Bull. Environ. Contam. Toxicol., 103 (2019) 468. https://doi.org/10.1007/s00128-019-02673-3

25. K. Ahmad, K. Wajid, Z. I. Khan, I. Ugulu, H. Memoona, M. Sana, K. Nawaz, I. S. Malik, H. Bashir and M. Sher, Bull. Environ. Contam. Toxicol., 102 (2019) 822. https://doi.org/10.1007/s00128-019-02605-1

26. Z. I. Khan, H. Safdar, K. Ahmad, K. Wajid, H. Bashir, I. Ugulu and Y. Dogan, Environ. Sci. Pollut. Res., 26 (2019) 14277. https://doi.org/10.1007/s11356-019-04721-1

27. Z. I. Khan, N. Arshad, K. Ahmad, M. Nadeem, A. Ashfaq, K. Wajid, H. Bashir, M. Munir, B. Huma, H. Memoona, M. Sana, K. Nawaz, M. Sher, T. Abbas and I. Ugulu, Environ. Sci. Pollut. Res., 26 (2019) 15381. https://doi.org/10.1007/s11356-019-04959-9

28. I. Ugulu, Int. J. Educ. Sci., 28 (2020) 7. https://doi.org/10.31901/24566322.2020/28. $1-3.1088$

29. S. Farooq, A. Barki, M.Y. Khan and H. Fazal, Pak. J. Weed Sci. Res., 18 (2012) 277. https://www.wssp.org.pk/weed/resources/im ages/paper/18WQ1450364169.pdf
30. T. M. Chiroma, R. O. Ebewele and F. K. Hymore, Int. Refereed J. Eng. Sci., 3 (2014) 1. http://dx.doi.org/10.183X/A03020109

31. USEPA. Preliminary remediation goals, Region 9. United States Environmental Protection Agency, Washington, DC. (2002).

32. N. Alrawiq, J. Khairiah, M.L. Talib, B.S. Ismail and S. Anizan, Int. J. Chem. Tech. Res., 6 (2014) 2347.

http://www.sphinxsai.com/2014/vol6pt4/2/( 2347-2356)Jul-Aug14.pdf

33. K. Ahmad, Z.I. Khan, S. Yasmin, M. Ashraf and A. Ishfaq, Pak. J. Bot., 46 (2014) 1805. https://www.pakbs.org/pjbot/PDFs/46(5)/35. pdf

34. S. M. Dogheim, E. M. M. Ashraf, S. A. G. Alla, M. A. Korshid and S. M. Fahmy, Food Add. Contam., $21 \quad$ (2004) 323. https://doi.org/10.1080/02652030310001656 $\underline{361}$

35. S. Gupta, V. Jena, S. Jena, N. Davic, N. Matic, D. Radojevic and J. S. Solanki, Croatian J. Food Sci. Tech. 5 (2013) 53. https://bib.irb.hr/datoteka/1016071.MANUS CRIPT_GUPTA_5.pdf

36. W.H. Liu, J.Z. Zhao, Z.Y. Ouyang, L. Soderlund and G.H. Liu, Environ. Int., 31 (2005) 805.

https://doi.org/10.1016/j.envint.2005.05.042

37. D. Demirezen and A. Aksoy, J. Food Qual., 29 (2006) 252.

https://doi.org/10.1111/j.17454557.2006.000 72.x

38. A. Mahmood and R. N. Malik, Arab. J. Chem., $\quad 7 \quad$ (2014) 91. https://doi.org/10.1016/j.arabjc.2013.07.002

39. K. Wajid, K. Ahmad, Z.I. Khan, M. Nadeem, H. Bashir, F. Chen and I. Ugulu, Bull. Environ. Contam. Toxicol., 104 (2020) 649. https://doi.org/10.1007/s00128-020-02841$\underline{\mathrm{w}}$

40. I. Ugulu, M.C. Unver and Y. Dogan, EuroMediterr. J. Environ. Integr., 4 (2019) 36. http://dx.doi.org/10.1007/s41207-019-0128$\underline{7}$ 